Editorial

\title{
Materials Research - Revista Ibero-americana de Materiais Criteriosa, justa e educativa!
}

É com satisfação que encerramos o quarto ano da Materials Research (Mat. Res.) com a publicação de um volumoso exemplar. A Materials Research entrou em regime estacionário, pois, além da expressiva carteira de trabalhos, dispomos de recursos suficientes para editar os próximos números. Visando aumentar a divulgação da revista, enviamos carta convite e alguns exemplares a uma centena de bibliotecas de universidades ibero-americanas que mantêm cursos de engenharia e ciência dos materiais.

É também prazeroso informar que iniciaremos, a partir deste número, parceria com a revista eletrônica Matéria. Publicaremos os abstracts do número correspondente da Matéria, enquanto os artigos completos da Mat. Res. serão disponibilizados em forma eletrônica no site daquela revista. Essa prática deverá contribuir para otimizar a divulgação de ambas.

Inúmeras pessoas têm nos perguntado sobre a abreviação oficial da Materials Research. O Scielo, que indexa os principais periódicos nacionais, a definiu como Mat. Res. Portanto, é dessa forma de deveremos citá-la para indexação eletrônica.

Negociamos com o Prof. Vladimir Trava Airoldi a edição de um número temático da Mat. Res. com artigos selecionados do IV Brazilian Meeting on Diamond, DLC, Carbon Nanotubes, Nitride and Silicon Carbide, - a ser realizado no próximo ano. Cinquenta e cinco trabalhos completos foram submetidos ao II Simpósio Brasileiro de Estruturologia e já estão sendo analisados. Dez trabalhos apresentados no Congresso Latino-americano de Mecânica de Fratura, realizado em Buenos Aires, foram selecionados pelo comitê científico do mesmo e estão sendo analisados pelos revisores da Mat. Res. Com a realização, em dezembro próximo, do I Simpósio Mineiro de Ciência dos Materiais, também teremos um novo conjunto de artigos. Essa expressiva carteira de trabalhos, somada aos artigos submetidos continuamente, garantirá a regularidade da revista em 2002.

O próximo ano será extremamente ativo para a área de Ciência e Engenharia de Materiais, pois, além dos congressos promovidos pelas diversas associações, será realizado, no final do ano, o $15^{\circ}$ CBECIMAT, em Natal-RN. Conjuntamente, o número de trabalhos sobre materiais apresentados nesses congressos deverá ser próximo a 4.000 ! Convidamos os leitores a apresentarem seus bons trabalhos ao crivo das platéias desses congressos, e logo após submeterem alguns deles à Mat. Res.

Os recursos para a editoração, produção e impressão deste décimo-terceiro número da Mat. Res. foram provenientes da FAPESP (aos autores vinculados a instituições paulistas) e do CNPq. Agradecemos aos organizadores do $14^{\circ}$ CBECIMAT que repassaram parte do saldo daquele evento para a Mat. Res. O auxílio financeiro do Departamento de Engenharia de Materiais- DEMa/UFSCar para as despesas de correio, do LaMaV/UFSCar para as despesas com fax e telefone e do NIT/UFSCar pela criação e manutenção da home-page têm sido fundamental. Agradecemos também a ABM pela manutenção da assistente editorial. As secretarias da ABC, ABPol e ABM têm efetuado o gerenciamento das assinaturas e dos recursos financeiros.

Cordialmente

Edgar Dutra Zanotto Editor Principal 30-10-2001 